\title{
Antimicrobial properties of 6-bromoeugenol and eugenol
}

\author{
Radia Mahboub* and Faiza Memmou \\ Department of Chemistry, Faculty of Sciences, University of Tlemcen, B.P. 119, Tlemcen, \\ 13 000, Algeria. \\ *E-mail: radiamahboub@yahoo.com
}

\begin{abstract}
Keywords: 6-Bromoeugenol, Eugenol, Antimicrobial activity, Activity coefficient.
\end{abstract}
\begin{abstract}
We have studied the antimicrobial properties of 6-bromoeugenol and eugenol by three strains: Pseudomonas aeruginosa (S1), Escherichia coli (S2) and Staphylococcus aureus (S3). We have determined the minimum inhibitory concentration (MIC) for a range of concentrations using the disc diffusion method. We note that all samples present an antimicrobial activity toward the tested bacterial strains at different concentrations $(1,0.5$ and $0.25 \mathrm{mg} / \mathrm{ml})$. The 6-bromoeugenol gives modest activity with $(S 1)$ and $(S 3)$. Eugenol reacts positively with the Pseudomonas aeruginosa $(\mathrm{S} 1)$ at all concentrations and with the Escherichia coli $(S 2)$ at $0.5 \mathrm{mg} / \mathrm{ml}$. We remark that the Pseudomonas aeruginosa $(S 1)$ is the more sensitive strain than Escherichia coli (S2) and Staphylococcus aureus (S3). We have estimated the activity coefficient which has confirmed the antimicrobial activity of the different samples. So, 6-bromoeugenol has shown his efficiency as antimicrobial agent.
\end{abstract}

\section{Introduction}

The antimicrobial activity of essential oil extracts are found in oxygenated compounds such as alcohols and phenolic derivatives. Furthermore, the hydrocarbons may also have antimicrobial effects $[1,2]$. Several studies have shown that essential oils have a higher antibacterial activity than their main components. Thus, the minority components of these essential oils may be the cause [35]. Lot of research group has studied the antimicrobial activity of medicinal plant extracts as: Digoxin (Digitalis lanata), Salicylic acid (Salix herbacea) and Inulin (Inula helenium). They have found these extracts are actives not only against bacteria but also against fungus, yeast and virus [6, 7]. Other groups have isolated and identified the metabolites responsible for the antimicrobial activity. This state constitutes a platform for several applications such as pharmaceutical industry, medicine and natural therapy [8-11]. Many papers have evaluated the different activities of eugenol, its derivatives and essential oils [12-15]. The free radical scavenging activity of 6-bromoeugenol and eugenol has studied. The 6-bromoeugenol has given the high antioxidant activity value [16]. So, the authors have shown the efficiency of the (S)-6,6'-dibromo-dehydrodieugenol as cytotoxic agent for melanoma [17]. Eugenol and 5-allyl-3-nitrobenzene-1,2-diol have given a high antioxidant capacity due to the presence of hydroxyl group o the aromatic ring [18]. The antimicrobial activity of epoxide-eugenol was evaluated and was found higher as achieved for eugenol [19]. We report here the antimicrobial activities of 6-bromoeugenol and eugenol.

\section{Materials and methods}

\subsection{Disc diffusion method}

6-Bromoeugenol was prepared from commercial eugenol [16]. To study the antibacterial activity of the samples, three strains have been used: Pseudomonas aeruginosa (ATCC 27853), Escherichia coli (ATCC 25922) and Staphylococcus aureus (ATCC 25293). The strains were stored at $5^{\circ} \mathrm{C}$ in sterile tubes containing $10 \mathrm{ml}$ of medium slope cultivation (nutrient agar). Thus, we have used the following media: the nutrient agar for the isolation and maintenance of bacterial strains, the Mueller Hinton agar to study the susceptibility of bacteria for various products. To evaluate the antibacterial activity of the above mentioned products, we have used the middle agar diffusion 
method. This method allows us to determine the minimum inhibitory concentration (MIC) for a range of concentrations.

From a pure culture of bacteria on isolation medium (nutrient agar medium) with a maximum of 24 hours, scraped with a sealed Pasteur pipette few well insulated and perfectly identical colonies. Then, the discharging Pasteur pipette in $10 \mathrm{ml}$ of sterile saline and homogenized bacterial suspension; opacity should be equivalent to $0.5 \mathrm{McFarland}$ or an OD of 0.08 to 0.10 , read at the wavelength of $620 \mathrm{~nm}$ corresponding to $10^{8} \mathrm{CFU} / \mathrm{ml}$ [20]. This method has allowed the identification of the antibacterial effect of the compounds tested on bacteria, as well as the determination of the resistance and the sensitivity of these strains by 6-bromoeugenol and eugenol.

The principle of this technique is the same as the antibiotic susceptibility test. The discs are loaded from the extract and deposited on the surface of the solid culture media Muller Hinton and seeded with well-defined bacterial species. The test sample starts broadcasting its application to the culture medium, and to promote bacterial growth, these plates are incubated in the incubator for 24 hours at $37^{\circ} \mathrm{C}$. The sample's effect on bacterial growth is reflected by the presence of the inhibition area devoid of bacteria. The same principle is followed for the positive control. The antibiotics used are: gentamicin, ampicillin, penicillin and chloramphenicol. The experimental results are expressed as the mean of the values obtained: standard deviation (SD).

\subsection{Determination of the minimum inhibitory concentration (MIC)}

The mother solution $(1 \mathrm{mg} / \mathrm{ml})$ is obtained by dissolution of $1 \mathrm{mg}$ of sample (6bromoeugenol and eugenol) in $1 \mathrm{ml}$ DMSO. To evaluate the MIC of each sample, different dilutions are prepared $(0.5$ and $0.25 \mathrm{mg} / \mathrm{ml})$ from the mother solution. The tests are repeated three times. Discs of $6 \mathrm{~mm}$ diameter are prepared with paper №1 Whatman, and autoclaved for 20 minutes at $120^{\circ} \mathrm{C}$ then are impregnated with various solutions of extracts previously dissolved in dimethylsulfoxide (DMSO). Discs are deposited on the surface of an inoculated medium (spread) by a microbial suspension with an optical density of $0.5 \mathrm{McFarland}$. After release, the dishes are incubated for 18 to 24 hours at $37^{\circ} \mathrm{C}$. After incubation, the samples effects appear as a transparent circular area corresponding to the absence of the growth record. The diameter of this area is the largest; so the strain is more sensitive [21]. Discs impregnated with DMSO or ethanol is also used as negative control. The antibacterial activity was determined by measuring the diameter of the inhibition area. The activity is determined for different concentrations of various samples and evaluated around inhibition discs [22].

\subsection{Determination of the activity coefficient (A)}

From the inhibitory diameter $\Phi$ and the volume of sample V, the inhibitory area S and the coefficient of activity A are estimated using the equations given as follow [23-25]:

$$
\begin{array}{lr}
\mathrm{A}=\mathrm{S} / \mathrm{V} & \text { Eq. } 1 \\
\mathrm{~S}=\pi\left(\Phi^{2} / 4\right) & \text { Eq. } 2
\end{array}
$$

Where S: inhibitory area $\left(\mathrm{cm}^{2}\right)$; V: volume of sample $(\mu \mathrm{l})$ and $\Phi$ : Inhibitory diameter $(\mathrm{mm})$. (Agar diameter included $(6 \mathrm{~mm})$ ). In this work, the volume of sample was taken equal to $20 \mu \mathrm{l}$.

\section{Results and discussion}

First, we have studied the sensitivity of the following antibiotics: gentamicin, ampicillin, penicillin and chloramphenicol on different bacterial strains using the disc diffusion method. The results are shown in Figure1. 


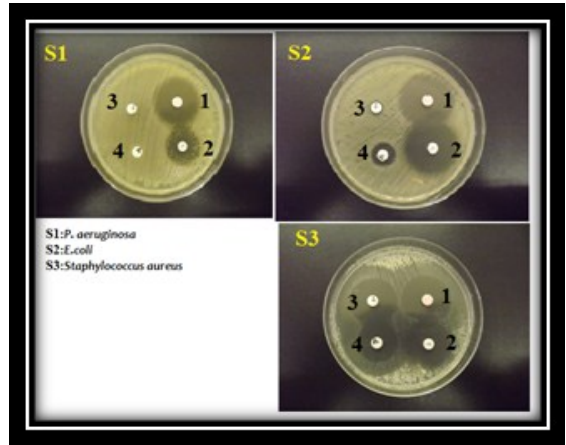

Fig. 1. Inhibitory areas of antibiotics on tested strains. 1, Gentamicine: Genta; 2, Ampicilline: Amp10; 3, Penicillin: P10 and 4, Chloramphenicol: C30.

We have observed that the bacterial strains react differently to the antibiotics. So, we remark that the gentamicin and ampicillin have a greater inhibitory area than $15 \mathrm{~mm}$. The two antibiotics are very sensitive to the used bacterial strains: Pseudomonas aeruginosa (S1), Escherichia coli (S2) and Staphylococcus aureus (S3).

Penicillin and chloramphenicol react differently to the strains. They express: no inhibition area with Pseudomonas aeruginosa (S1), middle activity with Escherichia coli (S2) and high activity with Staphylococcus aureus (S3). From these results, we conclude that Pseudomonas aeruginosa $(S 1)$ is resistant to penicillin and chloramphenicol (Figure 2).

Then, we have evaluated the antimicrobial activity of the following compounds: 6bromoeugenol and eugenol by the same method. Three bacterial strains: Pseudomonas aeruginosa (S1), Escherichia coli (S2) and Staphylococcus aureus (S3) are used for these tests. This test allows us to determine the minimum inhibitory concentration (MIC) from a range of concentrations by measuring the diameters of inhibition areas of microbial growth in round of discs, which represent the maximum antimicrobial activity. We note that the diameter of the inhibition area varies from one bacterium to another and from a sample to another. The variation of antimicrobial activity explains the variations in their chemical properties. These results are reported in Table 1.

Table 1. Antibacterial activity results of 6-bromoeugenol and eugenol.

\begin{tabular}{|c|c|c|c|c|c|c|}
\hline Sample & Strain & $(\mathrm{MIC})(\mathrm{mg} / \mathrm{ml})$ & $\Phi(\mathrm{mm})^{\mathrm{a}}$ & Sensitivity & $\mathrm{S}\left(\mathrm{cm}^{2}\right)^{\mathrm{b}}$ & $\mathrm{A}\left(\mathrm{cm}^{2} / \mu \mathrm{l}\right)^{\mathrm{c}}$ \\
\hline \multirow{3}{*}{$\begin{array}{l}\text { 6-Bromoeugenol } \\
\text { (BrEU) }\end{array}$} & $\begin{array}{c}\text { Pseudomonas aeruginosa } \\
\text { ATCC } 27853(S 1)\end{array}$ & 1.00 & 7 & Low & 0.384 & 0.0192 \\
\hline & $\begin{array}{c}\text { Escherichia coli } \\
\text { ATCC25922 (S2) }\end{array}$ & 1.00 & 6.5 & - & 0.331 & 0.0165 \\
\hline & $\begin{array}{l}\text { Staphylococcus aureus } \\
\text { ATCC } 25923(\mathrm{~S} 3)\end{array}$ & 0.5 & 7 & Low & 0.384 & 0.0192 \\
\hline \multirow{3}{*}{$\begin{array}{l}\text { Eugenol } \\
\text { (EU) }\end{array}$} & $\begin{array}{c}\text { Pseudomonas aeruginosa } \\
\text { ATCC } 27853(\mathrm{~S} 1)\end{array}$ & 0.25 & 8 & + & 0.502 & 0.025 \\
\hline & $\begin{array}{l}\text { Escherichia coli } \\
\text { ATCC25922 (S2) }\end{array}$ & 0.5 & 8 & + & 0.502 & 0.025 \\
\hline & $\begin{array}{l}\text { Staphylococcus aureus } \\
\text { ATCC } 25923(S 3)\end{array}$ & I & I & I & I & I \\
\hline \multirow{3}{*}{$\mathrm{DMSO}^{\mathrm{d}}$} & $\begin{array}{c}\text { Pseudomonas aeruginosa } \\
\text { ATCC } 27853(\text { S } 1)\end{array}$ & / & 6 & - & / & I \\
\hline & $\begin{array}{c}\text { Escherichia coli } \\
\text { ATCC25922 (S2) }\end{array}$ & I & 6 & - & I & I \\
\hline & $\begin{array}{l}\text { Staphylococcus aureus } \\
\text { ATCC } 25923(S 3)\end{array}$ & I & 6 & - & / & I \\
\hline
\end{tabular}

From Figure 2, we note that all samples present an antimicrobial activity toward the tested bacterial strains at three different concentrations: $1,0.5$ and $0.25 \mathrm{mg} / \mathrm{ml}$. The obtained diameters vary between 6.5 and $8 \mathrm{~mm}$. We also remark that the Pseudomonas aeruginosa (S1) is the more sensitive strain than Escherichia coli (S2) and Staphylococcus aureus (S3). The last one was particularly resistant microbial strain. 
The 6-bromoeugenol gives modest activity with $(S 1)$ and $(S 3)$ despite of $(S 2)$ where we note a low sensitivity at $1 \mathrm{mg} / \mathrm{ml}(\Phi=6.5 \mathrm{~mm})$. We observe that eugenol reacts positively with the Pseudomonas aeruginosa (S1) at all concentrations and with the Escherichia coli $(S 2)$ at $0.5 \mathrm{mg} / \mathrm{ml}$ $(\Phi=8 \mathrm{~mm})$. The Staphylococcus aureus $(S 3)$ does not be sensitive to eugenol. With $P$. aeruginosa $(S 1)$, we remark that all samples are less sensitive than gentamicin and ampicillin. However, the situation is reversed with penicillin and chloramphenicol which express no inhibition area. So, the samples have modest antimicrobial activity by comparing to the four antibiotics.

We observe that the $P$. aeruginosa (S1) shows an efficient sensitivity for all the samples (6bromoeugenol and eugenol) at different concentrations. In Figure 3, we give the inhibitory area obtained with Pseudomonas aeruginosa (S1) for the studied samples.

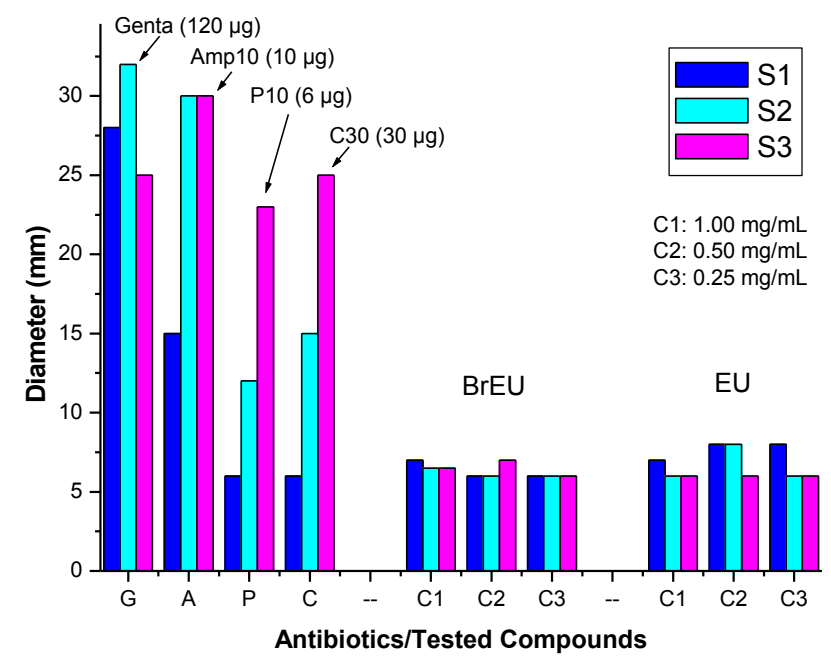

Fig. 2. Histogram of diameters vs. antibiotics and tested samples. Gentamicin (Genta: $120 \mu \mathrm{g} / \mathrm{disc}$ ), Ampicillin (Amp10: $10 \mu \mathrm{g} /$ disc), Penicillin (P10: $6 \mu \mathrm{g} /$ disc) and Chloramphenicol

(C30: $30 \mu \mathrm{g} /$ disc). 6-Bromoeugenol: BrEU and Eugenol, EU. P. aeruginosa: (S1), E. coli: $(S 2)$ and $S$. aureus: $(S 3)$.
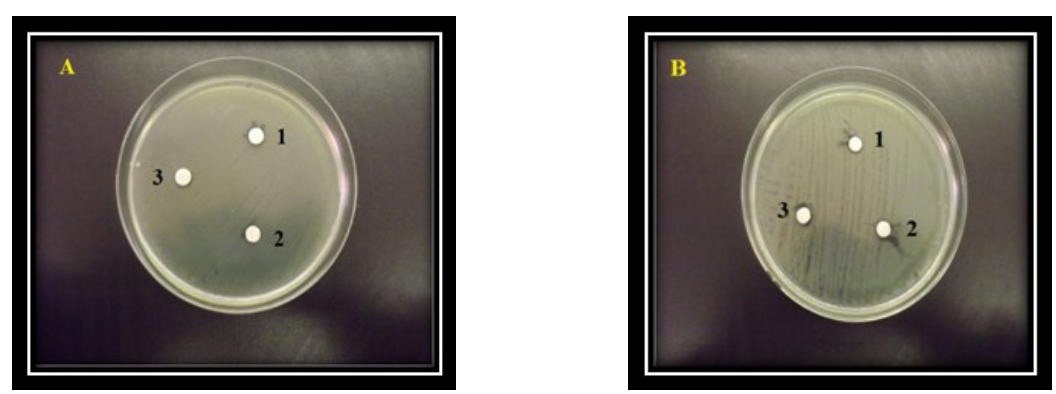

Fig. 3. Inhibitory areas obtained with Pseudomonas aeruginosa (S1). The following samples are used: A) 6-bromoeugenol and B) eugenol. 1: $\mathrm{C} 1=1 \mathrm{mg} / \mathrm{ml}$; $: \mathrm{C} 2=0.5 \mathrm{mg} / \mathrm{ml} ; 3$ : $\mathrm{C} 3=0.25 \mathrm{mg} / \mathrm{ml}$.

Next, we have determined the minimum inhibitory concentration (MIC) for the different strains. So, the $P$. aeruginosa (S1) shows an efficient sensitivity for all the samples (6bromoeugenol and eugenol) with MIC of $1,0.25,0.5,1$ and $0.25 \mathrm{mg} / \mathrm{ml}$ respectively (Table 1). The Escherichia coli (S2) are more sensitive to 6-bromoeugenol and eugenol with MIC of 1, 0.5, 0.25 and $0.5 \mathrm{mg} / \mathrm{ml}$ respectively. Staphylococcus aureus (S3) was very sensitive to 6-bromoeugenol with MIC of $0.5 \mathrm{mg} / \mathrm{ml}$ (Figure 4a). 


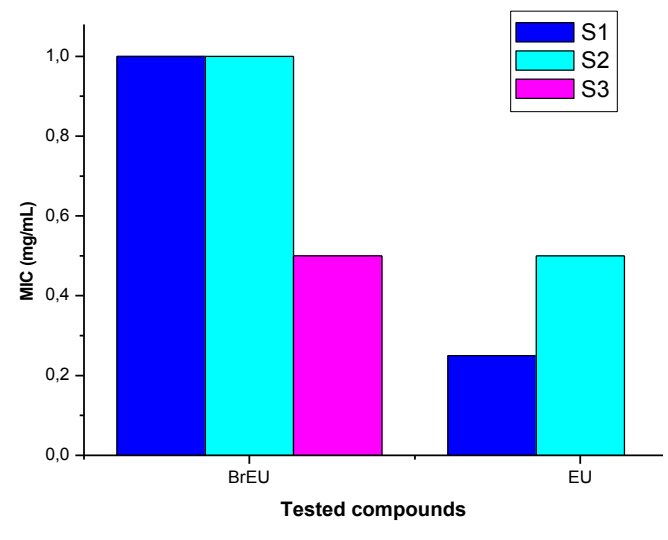

a)

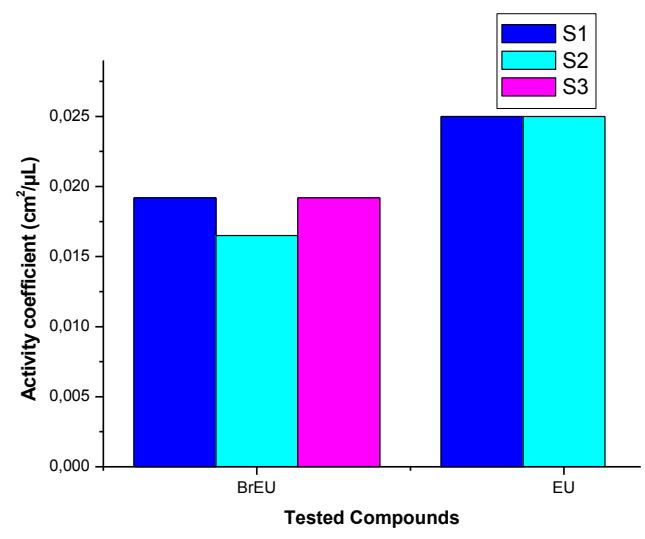

b)

Fig. 4. Histograms of: a) MIC and b) activity coefficient vs. tested samples. 6-Bromoeugenol: BrEU and Eugenol: EU. P. aeruginosa: (S1), E. coli: (S2) and S. aureus: (S3).

Finely, we have estimated the coefficient of activity A. So, the value of the activity coefficient $\mathrm{A}$ is given as follow: very sensitive strain is equal to1; sensitive strain is equal to 0.025 . However, the resistant microbial strain has a value less than 0.0192 . From Figure $4 \mathrm{~b}$, we can confirm that eugenol has more antimicrobial activity than 6-bromoeugenol. From these results, we conclude that the Staphylococcus aureus $(S 3)$ is resistant to eugenol. This study provides an activity coefficient order for the tested antimicrobial agents as follow: eugenol $(0.025)>6$-bromoeugenol (0.0192) (Table 1).

\section{Conclusions}

In this study, we have evaluated the antimicrobial properties of the synthetic products: 6bromoeugenol and eugenol. The strain of Staphylococcus aureus (S3) is revealed to be the most resistant. The Escherichia coli strain (S2) is more resistant than the Pseudomonas aeruginosa strain (S1). So, the Pseudomonas aeruginosa (S1) was found to be the most sensitive strain. We have determined the minimum inhibitory concentration (MIC) for a range of concentrations using the disc diffusion method. We have noted that all samples present an antimicrobial activity toward the tested bacterial strains at three different concentrations: $1,0.5$ and $0.25 \mathrm{mg} / \mathrm{ml}$. The evaluation of the activity coefficient has confirmed the antimicrobial activity of different samples. In addition, 6bromoeugenol has shown his efficiency as antimicrobial agent vis-à-vis eugenol. We can conclude that the antimicrobial activity depends of several factors like as the interaction between the microbial environment and the tested samples.

\section{Acknowledgement}

We gratefully acknowledge the laboratory of LAMMABE of Tlemcen for its substantial help to provide us the strains.

\section{References}

[1] S. Burt, Essential oils: Their antimicrobial properties and potential applications in foods: A review, International Journal of Food Microbiology. 94 (2004) 223-253.

[2] P.J. Delaquis, K. Stanich, B. Girard, G. Mazza, Antimicrobial activity of individual and mixed fractions of dill, cilantro, coriander and eucalyptus essential oils, International Journal of Food Microbiology. 74 (2002) 101-109.

[3] P.M. Davidson, M.E. Parish, Methods for testing the efficacy of food antimicrobials, Food Technology. 43 (1989) 148-155. 
[4] A.O. Gill, P. Delaquis, P. Russo, R.A. Holley, Evaluation of antilisterial action of cilantro oil on vacuum packed ham, International Journal of Food Microbiology. 3 (2002) 83-92.

[5] A. Mourey, N. Canillac, Anti-Listeria monocytogenes activity of essential oils components of conifers, Food Control. 13 (2002) 289-292.

[6] J. Reichling, P. Schnitzler, U. Suschke, R. Saller, Essential oils of aromatic plants with antibacterial, antifungal, antiviral, and cytotoxic properties-an overview, Forsch Komplementmed. 16 (2009) 79-90.

[7] A. Koroch, H.R. Juliani, J.A. Zygadlo, Flavours and Fragrances. Chemistry, Bioprocessing and Sustainability. Berger RG. Ed. Springer Verlag: Berlin, Germany, 2007, pp. 87-115.

[8] D. Nayak, A.P. Minz, A. Ashe, P.R. Rauta, M. Kumari, P. Chopra, B. Nayak, Synergistic combination of antioxidant, silver nanoparticles and chitosan in a nanoparticle based formulation: Characterization and cytotoxic effect on MCF-7 breas cancer cell lines. Journal of Colloid and Interface Science, (2016) In Press.

[9] J. Yi, Y. Fan, W. Yokoyama, Y. Zhang, L. Zhao, Thermal degradation and isomerization of beta-carotene in oil-in-water nanoemulsions supplemented with natural antioxidants, Journal of Agricultural and Food Chemistry, (2016) In Press.

[10] F. Frantianni, M.N.N. Ombra, A. Cozzolino, R. Riccardi, P. Spigno, P. Tremonte, R. Cppola, F. Nazzaro, Phenolic constituents, antioxidant, antimicrobial and anti-proliferaive activities of different endemic Italian varieties o garlic (Allium sativum L.), Journal of Functional Foods. 21 (2016) 240-248.

[11] G. Huang, J. Jiang, D. Dai, Antioxidative and antibacterial activity of the methanol extract of Artemisia anomala S. Moore, African Journal of Biotechnology. 7 (2008) 1335-1338.

[12] M.R.C. Raja, V. Srinivasan, S. Selvaraj, S.K. Mahapatra, Versatile and Synergistic potential of eugenol: a review, Pharmaceutica Analytica Acta. 6(5) 2015 367-372.

[13] F.G. Li, J.Chen, W.M. Cheng, M.F. Ji, Embrotoxicity of eugenol based on a model of embryonic stem cell test, Chinese Journal of Tissuse Engineering Research, 19(19) (2015) 30173021 .

[14] M. He, M. Du, M. Fa, Z. Bian, In vivo activity of eugenol against Candida albicans biofilm, Mycopathologia. 163 (2007)137-143.

[15] D. Huang, B. Ou, R.L. Prior, The chemistry behind antioxidant capacity assays, Journal of Agricultural and Food Chemistry. 53 (2005) 1841-1856.

[16] R. Mahboub, F. Memmou, Antioxidant activity and kinetics studies of eugenol and 6bromoeugenol, Natural Product Research. 29 (2015) 966-971.

[17] M. Pisano, G. Pagnan, M. Loi, M. E. Mura, M. G. Tilocca, G. Palmieri, D. Fabbri, M. A. Dettori, G. Delogu, M. Ponzoni, C. Rozzo, Antiproliferative and pro-apoptotic activity of eugenolrelated biphenyls on malignant melanoma cells, Molecular Cancer. 6 (2007) 1-12.

[18] M.E Hidalgo, C. De la Rosa, Antioxydant capcity of eugenol derivatives, Quimica Nova. 32 (2009) 1467-1470.

[19] G. Eyambe, L. Canale, B.K. Banik, Antimicrobial activity of eugenol derivatives, Heterocyclic Letters. 1 (2011) 154-157.

[20] S. Lamy, M. Blanchette, J. Michaud-Levesque, R. Lafleur, Y. Durocher, A. Moghrabi, S. Barrette, D. Gingras, R. Béliveau, Carcinogenesis. 27 (2006) 989-996.

[21] Y.M. Choi, D.O. Noh, S.Y. Cho, H.J. Suh, K.M. Kim, J.M. Kim, Antioxidant and antimicrobial activities of propolis from several regions of Korea, LWT-Food Science and Technology. 39 (2006) 756-761.

[22] S. Athamena, Etude quantitative des flavonoïdes des graines de Cuminum cyminum et les feuilles de Rosmarinus officinalis et l'évaluation de l'activité biologique. Thèse de Magister; Université de Batna, 2009.

[23] M.C. Pibiri, Assainissement microbiologique de l'air et des systèmes de ventilation au moyen d'huiles essentielles. Thèse $\mathrm{N}^{\circ} 3311$, Ecole Polytechnique Fédérale de Lausanne, 2006. 
[24] F. Haddouchi, H.A. Lazouni, A. Meziane, A. Benmansour, Etude physicochimique et microbilogique de l'huile essentielle de Thymus fontanesii Boiss et Reut, Afrique Science. 5 (2009) 246-259.

[25] J. El Amri, Kh. Elbadaoui, T. Zair, H. Bouharb, S. Chakir, T. Alaoui, Étude de l'activité antibactérienne des huiles essentielles de Teucrium capitatium $L$ et l'extrait de Siléne vulgaris sur différentes souches testées, Jouranal of Applied Biosciences. 82 (2014) 7481-7492.

\section{DOI References}

[1] S. Burt, Essential oils: Their antimicrobial properties and potential applications in foods: A review, International Journal of Food Microbiology. 94(3) (2004) 223-253.

10.1016/j.ijfoodmicro.2004/03.022

[2] P.J. Delaquis, K. Stanich, B. Girard, G. Mazza, Antimicrobial activity of individual and mixed fractions of dill, cilantro, coriander and eucalyptus essential oils, International Journal of Food Microbiology. 74(1) (2002) 101-109.

10.1016/S0168-1605(01)00734-6

[3] P.M. Davidson, M.E. Parish, Methods for testing the efficacy of food antimicrobials, Food Technology. 43(1) (1989) 148-155.

[4] A.O. Gill, P. Delaquis, P. Russo, R.A. Holley, Evaluation of antilisterial action of cilantro oil on vacuum packed ham, International Journal of Food Microbiology. 3(1) (2002) 83-92.

10.1016/S0168-1605(01)00712-7

[5] A. Mourey, N. Canillac, Anti-Listeria monocytogenes activity of essential oils components of conifers, Food Control. 13(4) (2002) 289-292.

10.1016/S0956-7135(02)00026-9

[6] J. Reichling, P. Schnitzler, U. Suschke, R. Saller, Essential oils of aromatic plants with antibacterial, antifungal, antiviral, and cytotoxic properties-an overview, Forsch Komplementmed.

16 (2) (2009) 79-90.

$10.1159 / 000207196$

[7] A.R. Koroch, H.R. Juliani, J.A. Zygadlo, Bioactivity of essential oils and their components, Flavours and Fragrances. Chemistry, Bioprocessing and Sustainability. Berger RG. Ed. Springer Verlag: Berlin, Germany, 2007, pp. 87-115.

10.1007/978-3-540-49339-6 5

[8] D. Nayak, A.P. Minz, A. Ashe, P.R. Rauta, M. Kumari, P. Chopra, B. Nayak, Synergistic combination of antioxidant, silver nanoparticles and chitosan in a nanoparticle based formulation: Characterization and cytotoxic effect on MCF-7 breas cancer cell lines. Journal of colloid and interface science, (2016) In Press.

10.016/j.jcis.2016.02.043

[9] J. Yi, Y. Fan, W. Yokoyama, Y. Zhang, L. Zhao, Thermal degradation and isomerization of beta-carotene in oil-in-water nanoemulsions supplemented with natural antioxidants, Journal of Agricultural and Food Chemistry, (2016) In Press.

10.1021/acs.jafc.5b05478

[10] F. Frantianni, M.N.N. Ombra, A. Cozzolino, R. Riccardi, P. Spigno, P. Tremonte, R. Cppola, F. Nazzaro, Phenolic constituents, antioxidant, antimicrobial and anti-proliferaive activities of different endemic Italian varieties o garlic (Allium sativum L.), Journal of Functional Foods. 21 (2016) 240-248.

10.1016/j.jff.2015.12.019

[11] G. Huang, J. Jiang, D. Dai, Antioxidative and antibacterial activity of the methanol extract of Artemisia anomala S. Moore, African Journal of Biotechnology. 7(9) (2008) 1335-1338.

10.5897/AJB07.822

[12] M.R.C. Raja, V. Srinivasan, S. Selvaraj, S.K. Mahapatra, Versatile and Synergistic potential of eugenol: a review, Pharmaceutica Analytica Acta. 6(5) 2015 367-372.

$10.4172 / 2153-2435.1000367$ 
[13] F.G. Li, J.Chen, W.M. Cheng, M.F. Ji, Embrotoxicity of eugenol based on a model of embryonic stem cell test, Chinese Journal of Tissue Engineering Research, 19(19) (2015) 30173021.

10.3969/j.issn2095-4344.2015.19.011

[14] M. He, M. Du, M. Fa, Z. Bian, In vivo activity of eugenol against Candida albicans biofilm, Mycopathologia. 163 (2007)137-143.

10.1007/s11046-007-0097-2

[15] D. Huang, B. Ou, R.L. Prior, The chemistry behind antioxidant capacity assays, Journal of Agricultural and Food Chemistry. 53(6) (2005) 1841-1856.

$10.1021 / \mathrm{jf0} 3723 \mathrm{c}$

[16] R. Mahboub, F. Memmou, Antioxidant activity and kinetics studies of eugenol and 6bromoeugenol, Natural Product Research. 29(10) (2015) 966-971.

10.1080/14786419.2014.958738

[17] M. Pisano, G. Pagnan, M. Loi, M. E. Mura, M. G. Tilocca, G. Palmieri, D. Fabbri, M. A. Dettori, G. Delogu, M. Ponzoni, C. Rozzo, Antiproliferative and pro-apoptotic activity of eugenolrelated biphenyls on malignant melanoma cells, Molecular Cancer. 6 (2007) 1-12.

10.1186/1476-4598-6-8

[18] M.E Hidalgo, C. De la Rosa, Antioxydant capcity of eugenol derivatives, Quimica Nova. 32 (2009) 1467-1470.

$10.1590 / \mathrm{S} 0100-40422009000620$

[19] G. Eyambe, L. CanaleS, B.K. Banik, Antimicrobial activity of eugenol derivatives, Heterocyclic Letters. 1(2) (2011) 154-157.

[20] S. Lamy, M. Blanchette, J. Michaud-Levesque, R. Lafleur, Y. Durocher, A. Moghrabi, S. Barrette, D. Gingras, R. Béliveau, Delphinidin, a dietary anthocyanidin, inhibits vascular endothelial growth factor receptor-2 phosphorylation, Carcinogenesis. 27(5) (2006) 989-996.

$10.1093 /$ carcin/bgi279

[21] Y.M. Choi, D.O. Noh, S.Y. Cho, H.J. Suh, K.M. Kim, J.M. Kim, Antioxidant and antimicrobial activities of propolis from several regions of Korea, LWT-Food Science and Technology. 39(9) (2006) 756-761.

10.1016/j.lwt.2005.05.015

[22] S. Athamena, Etude quantitative des flavonoïdes des graines de Cuminum cyminum et les feuilles de Rosmarinus officinalis et l'évaluation de l'activité biologique. Thèse de Magister; Université de Batna, 2009.

[23] M.C. Pibiri, Assainissement microbiologique de l'air et des systèmes de ventilation au moyen d'huiles essentielles. Thèse $\mathrm{N}^{\circ}$ 3311, Ecole Polytechnique Fédérale de Lausanne, 2006.

[24] F. Haddouchi, H.A. Lazouni, A. Meziane, A. Benmansour, Etude physicochimique et microbilogique de l'huile essentielle de Thymus fontanesii Boiss et Reut, Afrique Science. 5 (2009) 246-259.

[25] J. El Amri, Kh. Elbadaoui, T. Zair, H. Bouharb, S. Chakir, T. Alaoui, Étude de l'activité antibactérienne des huiles essentielles de Teucrium capitatium $L$ et l'extrait de Siléne vulgaris sur différentes souches testées, Journal of Applied Biosciences. 82 (2014) 7481-7492.

$10.4314 /$ jab.v82i1.15 